Prepared in cooperation with the U.S. Environmental Protection Agency

Geophysical Logs, Specific Capacity, and Water Quality of Four Wells at Rogers Mechanical (former Tate Andale) Property, North Penn Area 6 Superfund Site, Lansdale, Pennsylvania, 2006-07

Open-File Report 2010-1023 



\section{Geophysical Logs, Specific Capacity, and Water Quality of Four Wells at Rogers \\ Mechanical (former Tate Andale) Property, \\ North Penn Area 6 Superfund Site, \\ Lansdale, Pennsylvania, 2006-07}

By Lisa A. Senior and Philip H. Bird

Prepared in cooperation with the U.S. Environmental Protection Agency

Open-File Report 2010-1023 


\section{U.S. Department of the Interior \\ KEN SALAZAR, Secretary \\ U.S. Geological Survey \\ Marcia K. McNutt, Director}

U.S. Geological Survey, Reston, Virginia: 2010

For more information on the USGS - the Federal source for science about the Earth, its natural and living resources, natural hazards, and the environment, visit http://www.usgs.gov or call 1-888-ASK-USGS

For an overview of USGS information products, including maps, imagery, and publications, visit http://www.usgs.gov/pubprod

To order this and other USGS information products, visit http://store.usgs.gov

Any use of trade, product, or firm names is for descriptive purposes only and does not imply endorsement by the U.S. Government.

Although this report is in the public domain, permission must be secured from the individual copyright owners to reproduce any copyrighted materials contained within this report.

Suggested citation:

Senior, L.A., and Bird, P.H., 2010, Geophysical logs, specific capacity, and water quality of four wells at Rogers

Mechanical (former Tate Andale) property, North Penn Area 6 Superfund Site, Lansdale, Pennsylvania, 2006-07: U.S.

Geological Survey Open-File Report 2010-1023, 17 p. 


\section{Contents}

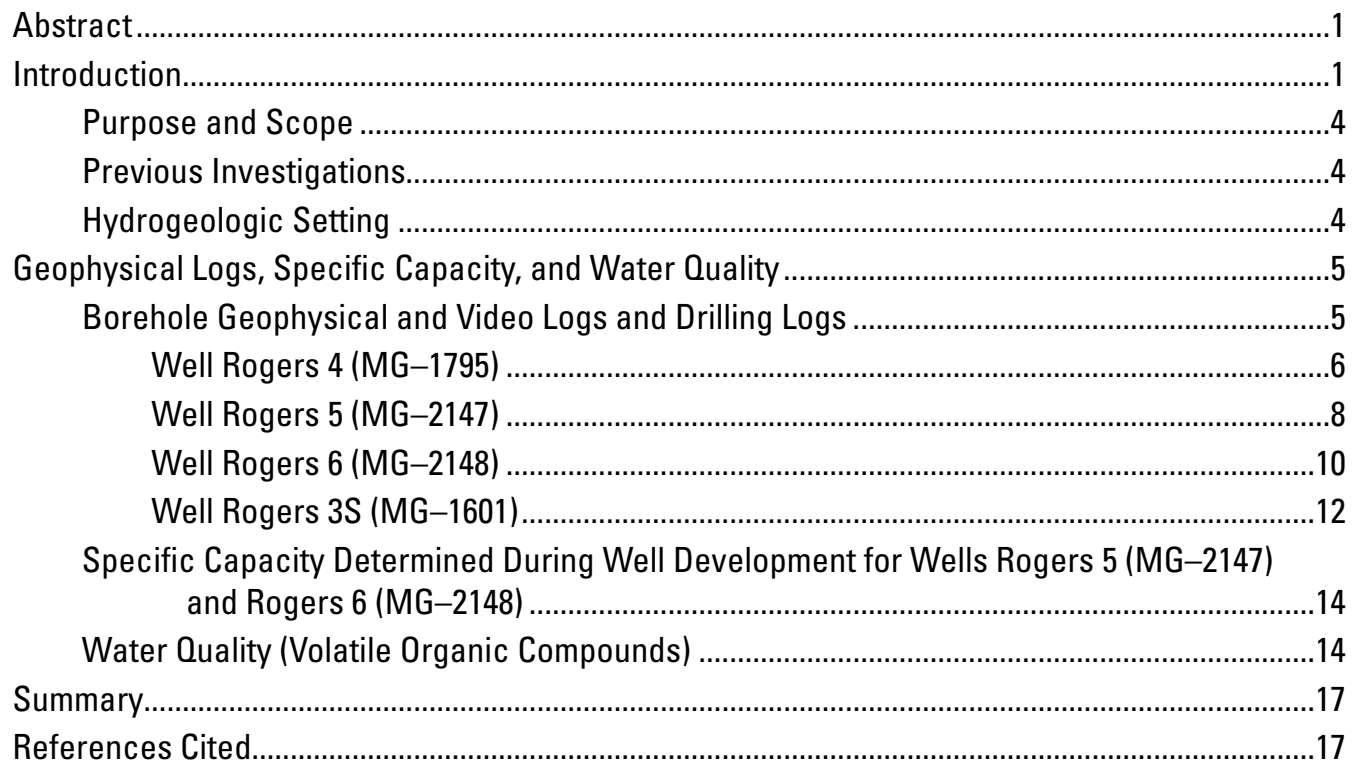

\section{Figures}

1. Map showing location of North Penn Area 6, and 10 identified sources of groundwater contamination including the Rogers Mechanical (former Tate Andale) Property, Lansdale, Montgomery County, Pa.

2. Map showing location of selected wells on and near the Rogers Mechanical (former Tate Andale) property, North Penn Area 6, Lansdale, Pa.

3. Borehole geophysical logs for well Rogers 4 (MG-1795) near the Rogers Mechanical property, North Penn Area 6 Superfund site, Lansdale, Pa., April 18, 2006

4. Borehole geophysical logs for well Rogers 5 (MG-2147) near the Rogers Mechanical property, North Penn Area 6 Superfund site, Lansdale, Pa., March 26, 2007.

5. Borehole geophysical logs for well Rogers 6 (MG-2148) near the Rogers Mechanical property, North Penn Area 6 Superfund site, Lansdale, Pa., March 26, 2007

6. Borehole geophysical logs for Rogers $3 S$ well (MG-1601) on the Rogers Mechanical property, North Penn Area 6 Superfund site, Lansdale, Pa., May 12, 1997, with borehole-flow rates measured on March 26, 2007

7. Graphs showing water levels measured during well development by pumping at various rates in $(A)$ well Rogers 5 (MG-2147) and $(B)$ well Rogers 6 (MG-2148) on the Rogers Mechanical property, North Penn Area 6 Superfund site, Lansdale, Pa., March 27, 2007 


\section{Tables}

1. Characteristics of existing well Rogers $3 S$ (MG-1601) and new wells, Rogers 4 (MG-1795), Rogers 5 (MG-2147), and Rogers 6 (MG-2148), drilled on and near the Rogers Mechanical property, North Penn Area 6 Superfund site, Lansdale, Pa., 2006-07

2. Borehole flow determined by heatpulse-flowmeter measurements in well Rogers 4 (MG-1795) under non-pumping, ambient conditions, Rogers Mechanical property, North Penn Area 6 Superfund Site, Lansdale, Pa., April 26, 2006

3. Drilling log for well Rogers 5 (MG-2147), at the Rogers Mechanical property, North Penn Area 6 Superfund site, Lansdale, Pa., March 26, $2007 .$.

4. Drilling log for well Rogers 6 (MG-2148), at the Rogers Mechanical property, North Penn Area 6 Superfund Site, Lansdale, Pa., March 26, 2007.

5. Borehole flow determined by heatpulse-flowmeter measurements in well Rogers $3 S$ (MG-1601) under non-pumping, ambient conditions at the Rogers Mechanical property, North Penn Area 6 Superfund Site, Lansdale, Pa., May 12, 1997 and April 24,2006

6. Depths of passive-diffusion bag placement and concentrations of selected volatile organic compounds in bag samples in wells Rogers 4 (MG-1795), Rogers 5

(MG-2147), Rogers 6 (MG-2148), and Rogers 3S (MG-1601), June 2006-May 2007, and in pumped samples from well Rogers 3S (MG-1601), October 1997 and September 2004, at the Rogers Mechanical property, North Penn Area 6, Lansdale, $\mathrm{Pa}$. 


\section{Conversion Factors}

Inch/Pound to SI

\begin{tabular}{|c|c|c|}
\hline Multiply & By & To obtain \\
\hline \multicolumn{3}{|c|}{ Length } \\
\hline inch (in.) & 2.54 & centimeter $(\mathrm{cm})$ \\
\hline inch (in.) & 25.4 & millimeter $(\mathrm{mm})$ \\
\hline foot $(\mathrm{ft})$ & 0.3048 & meter $(\mathrm{m})$ \\
\hline mile (mi) & 1.609 & kilometer $(\mathrm{km})$ \\
\hline \multicolumn{3}{|c|}{ Area } \\
\hline square mile $\left(\mathrm{mi}^{2}\right)$ & 259.0 & hectare (ha) \\
\hline square mile $\left(\mathrm{mi}^{2}\right)$ & 2.590 & square kilometer $\left(\mathrm{km}^{2}\right)$ \\
\hline \multicolumn{3}{|c|}{ Volume } \\
\hline gallon (gal) & 3.785 & liter $(\mathrm{L})$ \\
\hline gallon (gal) & 0.003785 & cubic meter $\left(\mathrm{m}^{3}\right)$ \\
\hline gallon (gal) & 3.785 & cubic decimeter $\left(\mathrm{dm}^{3}\right)$ \\
\hline \multicolumn{3}{|c|}{ Flow rate } \\
\hline gallon per minute (gal/min) & 0.06309 & liter per second $(\mathrm{L} / \mathrm{s})$ \\
\hline inch per year (in/yr) & 25.4 & millimeter per year (mm/yr) \\
\hline \multicolumn{3}{|c|}{ Specific capacity } \\
\hline $\begin{array}{l}\text { gallon per minute per foot } \\
[(\mathrm{gal} / \mathrm{min}) / \mathrm{ft})]\end{array}$ & 0.2070 & liter per second per meter $[(\mathrm{L} / \mathrm{s}) / \mathrm{m}]$ \\
\hline $\begin{array}{l}\text { gallon per minute per foot } \\
[(\mathrm{gal} / \mathrm{min}) / \mathrm{ft})]\end{array}$ & 17.899 & Meter squared per day $\left(\mathrm{m}^{2} / \mathrm{d}\right)$ \\
\hline \multicolumn{3}{|c|}{ Mass } \\
\hline microgram & 35.270 & ounce, avoirdupois (oz) \\
\hline milligram & 352.7 & ounce, avoirdupois (oz) \\
\hline
\end{tabular}

Temperature in degrees Celsius $\left({ }^{\circ} \mathrm{C}\right)$ may be converted to degrees Fahrenheit $\left({ }^{\circ} \mathrm{F}\right)$ as follows:

${ }^{\circ} \mathrm{F}=\left(1.8 \times{ }^{\circ} \mathrm{C}\right)+32$

Temperature in degrees Fahrenheit $\left({ }^{\circ} \mathrm{F}\right)$ may be converted to degrees Celsius $\left({ }^{\circ} \mathrm{C}\right)$ as follows:

${ }^{\circ} \mathrm{C}=\left({ }^{\circ} \mathrm{F}-32\right) / 1.8$

Vertical coordinate information is referenced to the North American Vertical Datum of 1988

(NAVD 88).

Horizontal coordinate information is referenced to the North American Datum of 1983 (NAD 83).

Altitude, as used in this report, refers to distance above the vertical datum.

Specific conductance is given in microsiemens per centimeter at 25 degrees Celsius $(\mu \mathrm{S} / \mathrm{cm}$ at $\left.25^{\circ} \mathrm{C}\right)$.

Concentrations of chemical constituents in water are given either in milligrams per liter (mg/L) or micrograms per liter $(\mu \mathrm{g} / \mathrm{L})$, which are approximately equivalent to parts per million $(\mathrm{ppm})$ or parts per billion (ppb), respectively. 



\title{
Geophysical Logs, Specific Capacity, and Water Quality of Four Wells at Rogers Mechanical (former Tate Andale) Property, North Penn Area 6 Superfund Site, Lansdale, Pennsylvania, 2006-07
}

\author{
by Lisa A. Senior and Philip H. Bird
}

\begin{abstract}
As part of technical assistance to the U.S. Environmental Protection Agency (USEPA) in the remediation of properties on the North Penn Area 6 Superfund Site in Lansdale, Pa., the U.S. Geological Survey (USGS) in 2006-07 collected data in four monitor wells at the Rogers Mechanical (former Tate Andale) property. During this period, USGS collected and analyzed borehole geophysical and video logs of three new monitor wells (Rogers 4, Rogers 5, and Rogers 6) ranging in depth from 80 to 180 feet, a borehole video log and additional heatpulse-flowmeter measurements (to quantify vertical borehole flow) in one existing 100-foot deep well (Rogers 3S), and water-level data during development of two wells (Rogers 5 and Rogers 6) to determine specific capacity. USGS also summarized results of passive-diffusion bag sampling for volatile organic compounds (VOCs) in the four wells. These data were intended to help understand the groundwater system and the distribution of VOC contaminants in groundwater at the property.
\end{abstract}

\section{Introduction}

The U.S. Geological Survey (USGS) provided technical assistance to the U.S. Environmental Protection Agency (USEPA) to help describe the fractured-rock groundwater system and effects of pumping on groundwater flow and associated distribution of contaminants at the North Penn Area 6 Superfund Site in Lansdale, Pa. (fig. 1). USGS assistance included, but was not limited to, collection of borehole geophysical logs and water-level data during the Remedial Investigation/Feasibility Study (RI/FS) from 1995 to 2000 and subsequently during remedial design activities since 2005. Groundwater at the North Penn Area 6 Superfund Site is contaminated with volatile organic compounds (VOCs), such as the solvent trichloroethylene (TCE), from numerous industrial sources in the Lansdale area (Black \& Veatch Waste Science, Inc., 1999). As part of the technical assistance, USGS worked in conjunction with the USEPA contractor Black \& Veatch Waste Science, Inc. (Black \& Veatch), who usually supervised drilling of new wells and collection of groundwater samples from 1995 through 2007.

The Rogers Mechanical (former Tate Andale) property is one of five properties currently (2009) being remediated by the USEPA; four of the other five properties identified as source areas are being remediated by property owners (fig. 1). During the RI/FS, results of sampling well water showed that groundwater at the property had elevated concentrations of TCE, tetrachloroethylene (PCE), 1,1-dichloroethylene (1,1-DCE) and carbon tetrachloride (Black \& Veatch Waste Science, Inc., 1999). As of 2004, known contamination in groundwater was greatest along the western side of the property (fig. 2) in monitor well Rogers 3S (MG-1601) and in the shallowest water-bearing intervals of the former production well (MG-1444) (Black \& Veatch Waste Science, Inc., 1999; Senior and Goode, 1999; Black \& Veatch Waste Science, Inc., written commun., 2004).

In 2006, the USEPA and its contractor, Black \& Veatch, drilled a new well, Rogers 4 (MG-1795), on a residential property located to the west of the Rogers Mechanical property across the railroad tracks and downdip of the old production well (MG-1444) (fig. 2). In 2007, the USEPA and its contractor, Black \& Veatch, drilled two wells, Rogers 5 and Rogers 6 (MG-2147 and MG-2148), on the Rogers Mechanical property, located updip of the old production well MG-1444 (fig. 2). As part of technical assistance to USEPA in 2006-07, the USGS collected geophysical logs in the new monitor wells (Rogers 4, Rogers 5, and Rogers 6), collected a borehole video log in one existing well (Rogers 3S), and measured water levels during well development in two monitor wells (Rogers 5 and Rogers 6). 


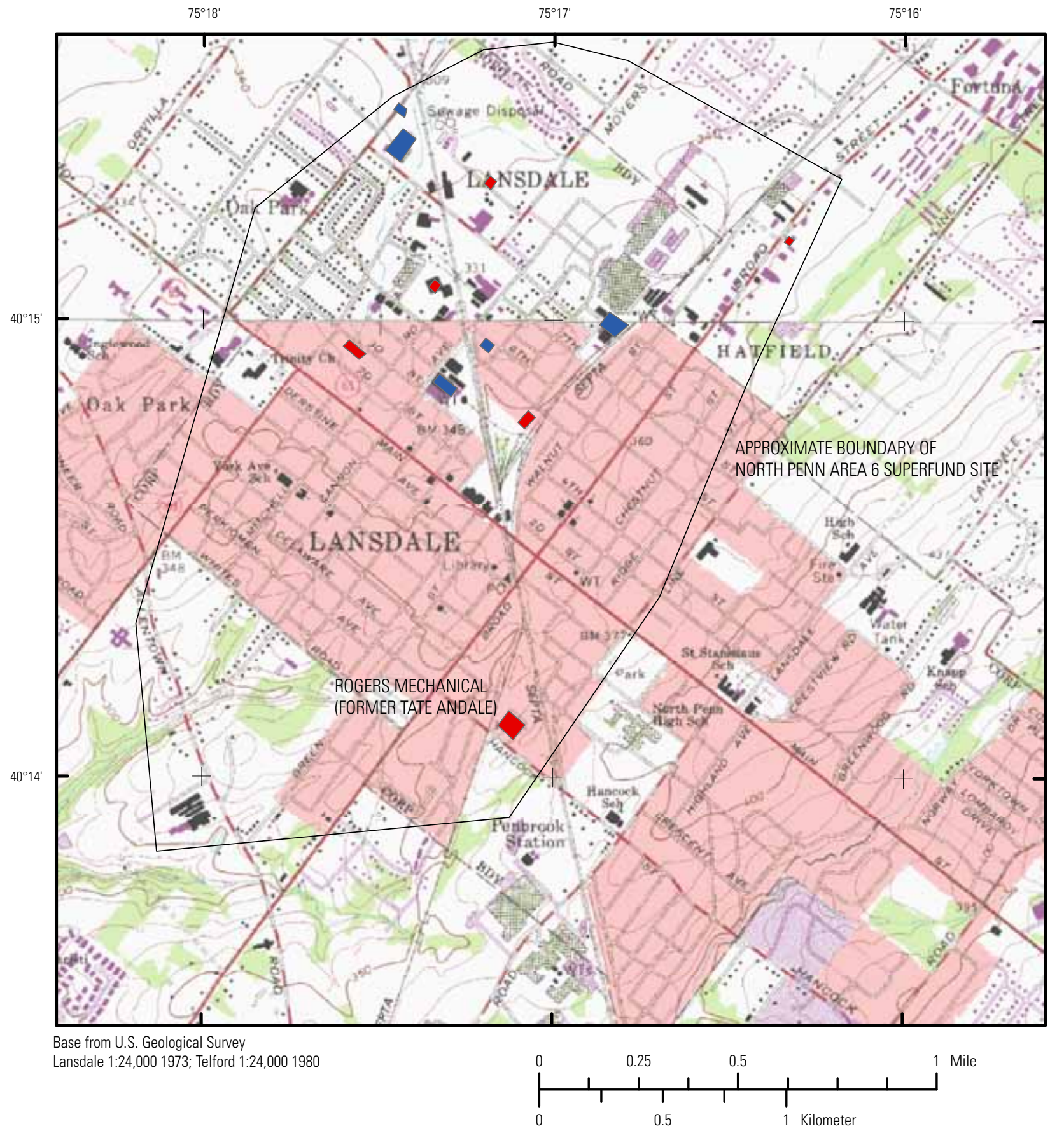

EXPLANATION

Contaminant source identified in North Penn Area 6 Superfund Site under U.S. Environmental Protection Agency remediation

Contaminant source identified in North Penn Area 6 Superfund Site under property owner remediation

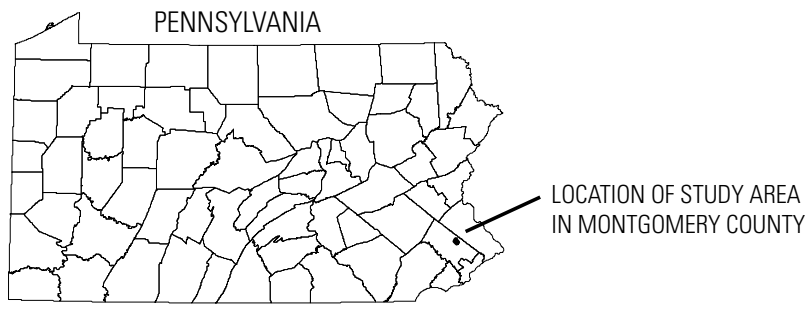

Figure 1. Location of North Penn Area 6, and 10 identified sources of groundwater contamination including the Rogers Mechanical (former Tate Andale) Property, Lansdale, Montgomery County, Pa. 


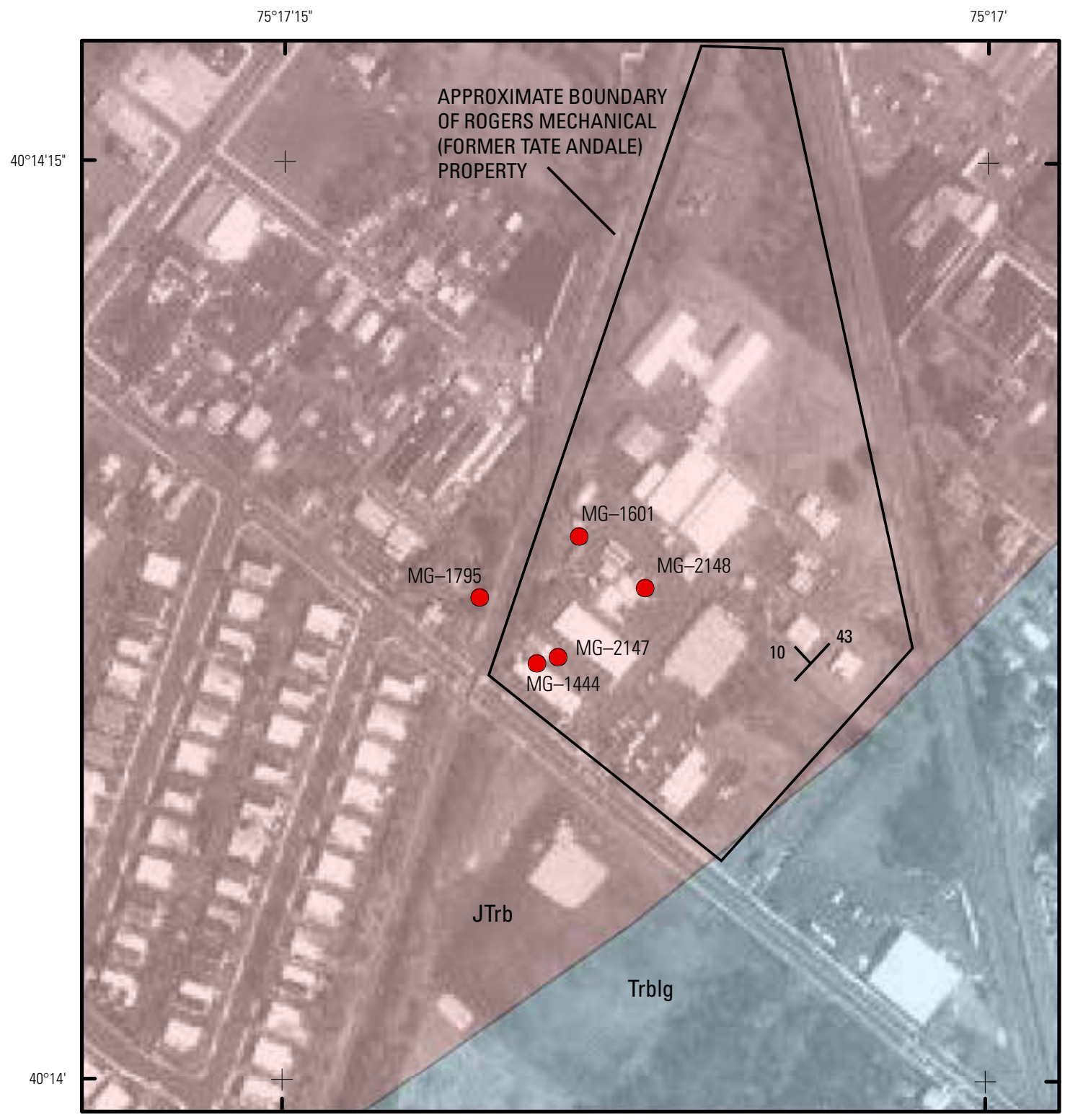

Base from U.S. Geological Survey

Geology from Lyttle and Epstein, 1987 Lansdale 1:24,000 Orthophoto Quadrangle, 1999

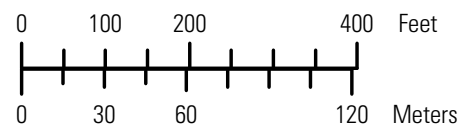

\section{EXPLANATION}

Geologic units

\section{JTrb}

Brunswick Group (red beds)

Brunswick Group gray beds
MG-2148

Well and U.S. Geological Survey well number

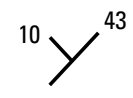

Direction and magnitude of bedrock strike and dip

Figure 2. Location of selected wells on and near the Rogers Mechanical (former Tate Andale) property, North Penn Area 6, Lansdale, Pa. Depicted geologic units dip to the northwest. 


\section{Purpose and Scope}

This report describes work done by the USGS during 2006-07 in four wells at the Rogers Mechanical property as part of technical assistance to the USEPA on the North Penn Area 6 Superfund Site from 2005 to present (2009). Work done by USGS at the property included collection of borehole geophysical and video logs in three new monitor wells [Rogers 4 (MG-1795), Rogers 5 (MG-2147), and Rogers 6 (MG-2148)], borehole video and heatpulse-flowmeter measurements in one existing well [Rogers 3S (MG-1601)], and water-level data during well development in two of the new monitor wells [Rogers 5 (MG-2147) and Rogers 6 (MG-2148)]. Discrete interval sampling data with passive-diffusion bags and whole-well sampling conducted by the USEPA contractor Black \& Veatch in 2006-07 in these four wells on the property also are summarized.

\section{Previous Investigations}

Work done by USGS during 1995-2000 at the North Penn Area 6 Superfund Site including near or on the Rogers Mechanical property is documented in Senior and others (1998), Goode and Senior (1998, 2000), Conger (1999), and Senior and Goode (1999).

\section{Hydrogeologic Setting}

The sedimentary bedrock units underlying North Penn Area 6 including the Rogers Mechanical property are mapped as two units of the Brunswick Group. One unit consists predominantly of red beds and the other unit consists of gray beds (Lyttle and Epstein, 1987) (fig. 2). In the study area, the geologic units strike northeast and dip northwest. These rocks form a leaky, layered, fractured-rock aquifer described in more detail by Senior and Goode (1999). 


\section{Geophysical Logs, Specific Capacity, and Water Quality}

The USGS collected drilling logs for the two wells, Rogers 5 (MG-2147) and Rogers 6 (MG-2148), drilled in 2007 and ran geophysical and borehole video logs of all three new wells [Rogers 4 (MG-1795), Rogers 5 (MG-2147), and Rogers 6 (MG-2148)] drilled near and on the Rogers Mechanical property in 2006-07. Well characteristics for the three new wells are listed in table 1. In addition, the USGS collected borehole video logs and a second set of heatpulse-flowmeter measurements in existing monitor well Rogers 3S (MG-1601) and collected water-level data during development of new wells Rogers 5 (MG-2147) and Rogers 6 (MG-2148). These water-level data document aquifer response to pumping and may be evaluated as short-duration pumping tests that provide information on potential well yields and specific capacity. Results of passive-diffusion bag sampling conducted by Black \& Veatch in 2006-07 and whole-well sampling conducted in 1997 and 2004 also are summarized to help describe distribution of VOC contaminants at the property in relation to the groundwater system.

\section{Borehole Geophysical and Video Logs and Drilling Logs}

Results of borehole geophysical and video logging are described for each well, in approximate order of date of logging from April 2006 through April 2007. A suite of geophysical logs, consisting of caliper, natural-gamma, single-point resistance, fluid temperature, fluid resistivity, and heatpulse flowmeter (to measure vertical borehole flow), was collected on the three new wells and used to identify water-bearing zones, direction of vertical borehole flow, and lithologic changes. Using a diverter with the same diameter as the borehole, the heatpulse flowmeter is capable of measuring vertical borehole flow in the range of 0.1 to $1.0 \mathrm{gal} / \mathrm{min}$. Natural-gamma and single-point-resistance logs indicate lithology and may be used in conjunction with logs for other wells to infer stratigraphic correlation. Borehole features also were identified where possible using borehole video logs (on file at U.S. Geological Survey, Exton, Pa.) and pertinent observations from logs are presented. Borehole video and heatpulseflowmeter logs only were collected in well Rogers 3S (MG-1601) in April 2007, because other geophysical logs in the suite were collected previously in 1997 (Conger, 1999). In addition, drilling logs recorded by USGS are presented for new wells Rogers 5 (MG-2147) and Rogers 6 (MG-2148).

Table 1. Characteristics of existing well Rogers $3 S$ (MG-1601) and new wells, Rogers 4 (MG-1795), Rogers 5 (MG-2147), and Rogers 6 (MG-2148), drilled on and near the Rogers Mechanical property, North Penn Area 6 Superfund Site, Lansdale, Pa., 2006-07.

[USGS, U.S. Geological Survey; DDMMSS, degrees minutes seconds; NAD 83, North American Datum of 1983; ft bls, feet below land surface]

\begin{tabular}{|c|c|c|c|c|c|c|c|c|c|}
\hline Well name & $\begin{array}{c}\text { USGS well } \\
\text { number }\end{array}$ & $\begin{array}{l}\text { Latitude, in } \\
\text { DDMMSS } \\
\text { NAD } 83\end{array}$ & $\begin{array}{c}\text { Longitude } \\
\text { (DDMMSS } \\
\text { NAD 83) }\end{array}$ & $\begin{array}{l}\text { Date } \\
\text { drilled }\end{array}$ & $\begin{array}{l}\text { Well depth } \\
\text { (ft bls) }\end{array}$ & $\begin{array}{l}\text { Casing } \\
\text { length } \\
\text { (ft bls) }\end{array}$ & $\begin{array}{c}\text { Well } \\
\text { diameter } \\
\text { (inches) }\end{array}$ & $\begin{array}{l}\text { Date } \\
\text { logged by } \\
\text { USGS }\end{array}$ & $\begin{array}{c}\text { Static } \\
\text { water } \\
\text { level when } \\
\text { logged } \\
\text { (ft bls) }\end{array}$ \\
\hline Rogers 3S & MG-1601 & 401409 & 751707 & $4 / 25 / 1997$ & 100 & 19 & 6 & $4 / 4 / 2007$ & 56.13 \\
\hline Rogers 4 & MG-1795 & 401408 & 751709 & $4 / 18 / 2006$ & 180 & 19 & 6 & $4 / 26 / 2006$ & 57.30 \\
\hline Rogers 6 & MG-2148 & 401408 & 751706 & $3 / 26 / 2007$ & 80 & 22 & 6 & $4 / 4 / 2007$ & 59.13 \\
\hline
\end{tabular}




\section{Well Rogers 4 (MG-1795)}

The caliper log indicated numerous fractures throughout the 180 - $\mathrm{ft}$ borehole especially from 19 to $125 \mathrm{ft}$ (fig. 3). Possible water-bearing fractures indicated on the caliper log and observed on the borehole video log were at 89-92, 108, 122-124, 135, and $171 \mathrm{ft}$ below land surface (bls). Static water level at the time of logging was $57.30 \mathrm{ft}$ bls. The drilling log collected by Black \& Veatch noted water production near 89, 129, and $150 \mathrm{ft}$ bls (Black \& Veatch, written commun., April 25, 2006). Total well yield was about $10 \mathrm{gal} / \mathrm{min}$. Cumulative yields measured as the well was drilled are as follows: $3-4 \mathrm{gal} / \mathrm{min}$ at $89 \mathrm{ft}$ bls, $7-8 \mathrm{gal} / \mathrm{min}$ at $129 \mathrm{ft} \mathrm{bls}$, and $10 \mathrm{gal} / \mathrm{min}$ at $150 \mathrm{ft}$ bls. Soft zones and fractures were noted at 107-109 and 171-173 ft bls.

The natural-gamma log shows low activity throughout most of the borehole with two thin zones of elevated activity near 136-138 and 140-142 ft bls that could be used for stratigraphic correlation. These thin zones of elevated gamma activity probably correlate with a similar zone at about $120 \mathrm{ft}$ bls in the old production well MG-1444 previously logged (Conger, 1999) on the Rogers Mechanical property (fig. 2). Correlation of elevated natural-gamma zones in wells at the Rogers property resulted in an estimated bedding strike of N. $43^{\circ} \mathrm{E}$. and a dip of $10^{\circ} \mathrm{NW}$. (Conger, 1999). The zones of elevated natural-gamma activity in the well Rogers 4 (MG-1795) probably correspond to black or gray units observed on the borehole video and drilling logs. A sharp lithologic change to black shale was noted on the borehole video log at $135 \mathrm{ft}$ bls. The drilling log records red siltstone at about 9-34 ft bls, red shale at 34-136 ft bls, light gray shale at 136-147 ft bls, and red shale at 147-180 ft bls (Black \& Veatch, written commun., April 25, 2006).

The fluid-temperature log shows small inflections near 75 and $125 \mathrm{ft}$ bls that may indicate water-bearing zones. The fluid-resistivity log is a nearly straight profile, with a change in slope at about $80 \mathrm{ft}$ bls and possible minor inflections at about 103-106, 130, and $145 \mathrm{ft}$ bls, and does not strongly indicate any water-bearing zone. Under non-pumping (ambient) conditions, the heatpulse-flowmeter logs show that no vertical flow was detected at 70,84, and $175 \mathrm{ft}$ bls; downward flow was measured at $100,104,112$, and $120 \mathrm{ft}$ bls; and upward flow was measured at 144 and $161 \mathrm{ft}$ bls (fig. 3; table 2). The flowmeter measurements indicate that, at the time of logging, water entered the borehole through fractures at 89-92 and 107-109 ft bls, moved down, and exited the borehole through fractures at 122-124 ft bls. Additionally, a small amount of water appeared to enter the borehole through fractures at about $171 \mathrm{ft}$ bls and move up to exit the borehole through the fracture at 122-124 ft bls. Thus, active waterbearing zones were identified at 89-92, 107-109, 122-124, and $171 \mathrm{ft}$ bls. Other water-bearing zones may be present in the well that were not detected under non-pumping conditions.

Table 2. Borehole flow determined by heatpulse-flowmeter measurements in well Rogers 4 (MG-1795) under non-pumping, ambient conditions, Rogers Mechanical property, North Penn Area 6 Superfund Site, Lansdale, Pa., April 26, 2006.

[ft bls, feet below land surface; gal/min, gallon per minute; NF, no flow detected; --, no data]

\begin{tabular}{ccc}
\hline $\begin{array}{c}\text { Depth of measurement } \\
\text { (ft bls) }\end{array}$ & $\begin{array}{c}\text { Measured flow } \\
\text { (gal/min) }\end{array}$ & $\begin{array}{c}\text { Direction } \\
\text { of flow }\end{array}$ \\
\hline 70 & $\mathrm{NF}$ & -- \\
84 & $\mathrm{NF}$ & -- \\
100 & 0.42 & down \\
104 & .58 & down \\
112 & .66 & down \\
120 & .69 & down \\
144 & .04 & up \\
160 & .04 & up \\
175 & $\mathrm{NF}$ & -- \\
\hline
\end{tabular}



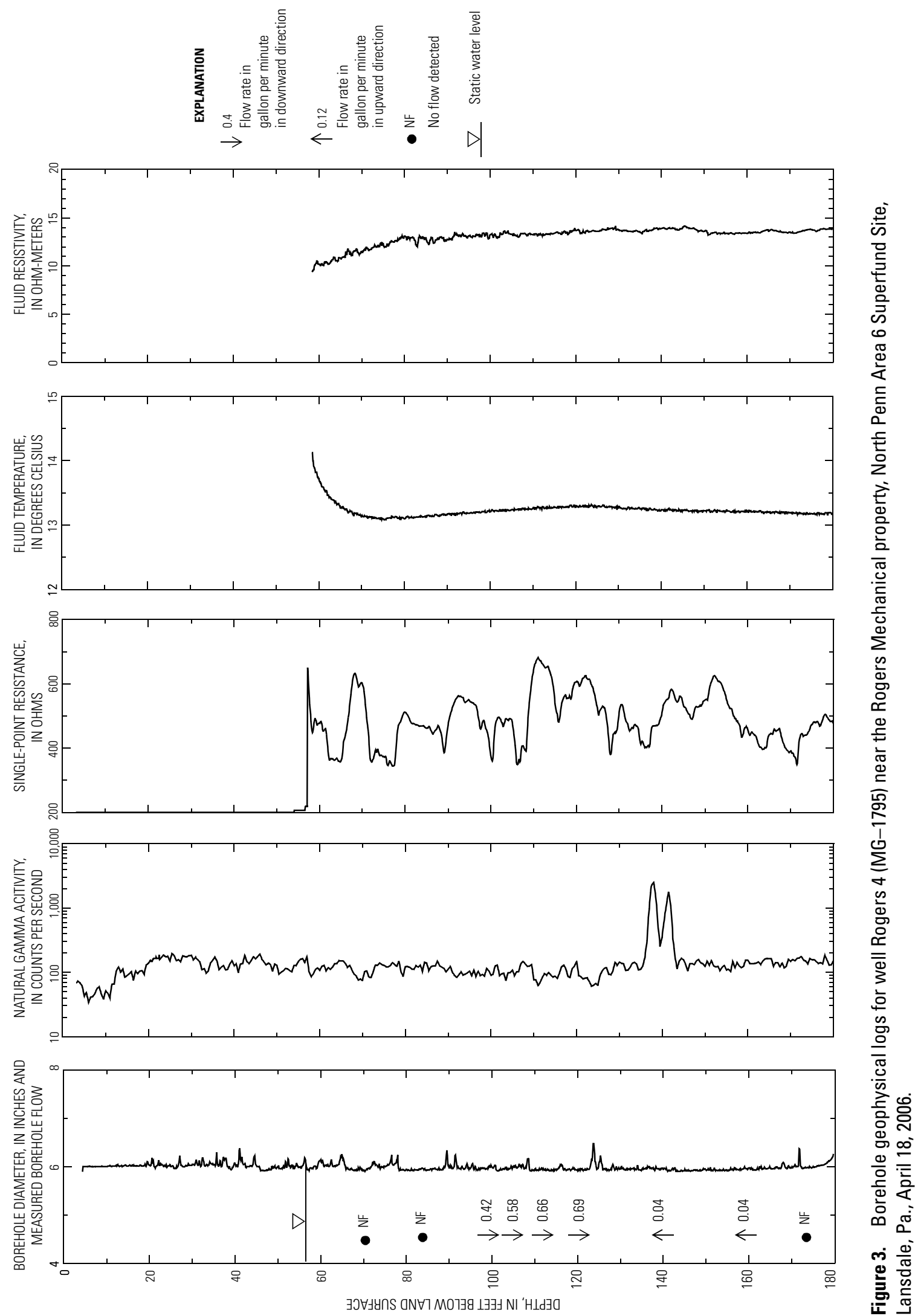
Well Rogers 5 (MG-2147)

The caliper log shows numerous fractures throughout the 82 -ft borehole, with large fractures indicated at about 22,32 , 58-61, 68-71, and 73-77 ft bls (fig. 4). Possible water-bearing fractures indicated on the caliper log and noted on the borehole video $\log$ were at $67-70$ and $71-75 \mathrm{ft}$ bls. Static water level at the time of logging was $60.58 \mathrm{ft}$ bls. The drilling $\log$ collected by USGS (table 3) noted possible water at 68-70 ft bls and total water production near $80 \mathrm{ft}$ bls at about $2 \mathrm{gal} / \mathrm{min}$.

The natural-gamma log shows relatively low activity throughout the borehole, with features of depressed activity about $61 \mathrm{ft}$ bls and in the interval 70-77 ft bls that might possibly be used for log correlation. The single-point resistance log shows an increase in resistance from 68-76 ft bls that appears to correspond with water-bearing fracture zones and relatively lower gamma activity that may correspond to relatively coarser-grained (sandier) sediments. The drilling log (table 3 ) recorded red shale at about 20-55 ft bls, dark-red to gray shale at 55-65 ft bls, and various shades of gray shale at 65-82 ft bls, with yellow-brown to gray shale at $70 \mathrm{ft}$ bls and dark gray-to-black shale at $75-80 \mathrm{ft}$ bls.

The fluid-temperature log shows a decrease in temperature with depth from water level at $60 \mathrm{ft}$ bls to the bottom of the borehole at $82 \mathrm{ft}$ bls, with very slight inflections near 66,70 , and $78 \mathrm{ft}$ bls that may indicate water-bearing zones. The fluid-resistivity $\log$ is a nearly straight profile and does not indicate any water-bearing zone. Under non-pumping conditions, no vertical flow was detected at $63 \mathrm{ft}$. The suite of caliper, borehole video, temperature, and drilling logs indicates that water-bearing zones in the well probably are in the interval between 68 and $76 \mathrm{ft}$ bls.

Table 3. Drilling log for well Rogers 5 (MG-2147), at the Rogers Mechanical property, North Penn Area 6 Superfund Site, Lansdale, Pa., March 26, 2007.

\begin{tabular}{|c|c|c|}
\hline $\begin{array}{c}\text { Depth } \\
\text { (feet below land surface) }\end{array}$ & Lithology & Remarks \\
\hline 20 & red shale & \\
\hline 25 & red shale, fine & \\
\hline 30 & red shale & \\
\hline 35 & red shale & \\
\hline 40 & red shale & \\
\hline 45 & red shale & \\
\hline 50 & red shale & \\
\hline 55 & dark red shale & \\
\hline 60 & red shale & \\
\hline 65 & medium gray shale & \\
\hline 70 & yellow-brown to gray shale & some water at $68-70$ feet below land surface \\
\hline 75 & gray-to-black shale & graphite floating \\
\hline 80 & gray-to-black shale & total yield about 2 gallons per minute \\
\hline 82 & medium gray shale & total depth \\
\hline
\end{tabular}



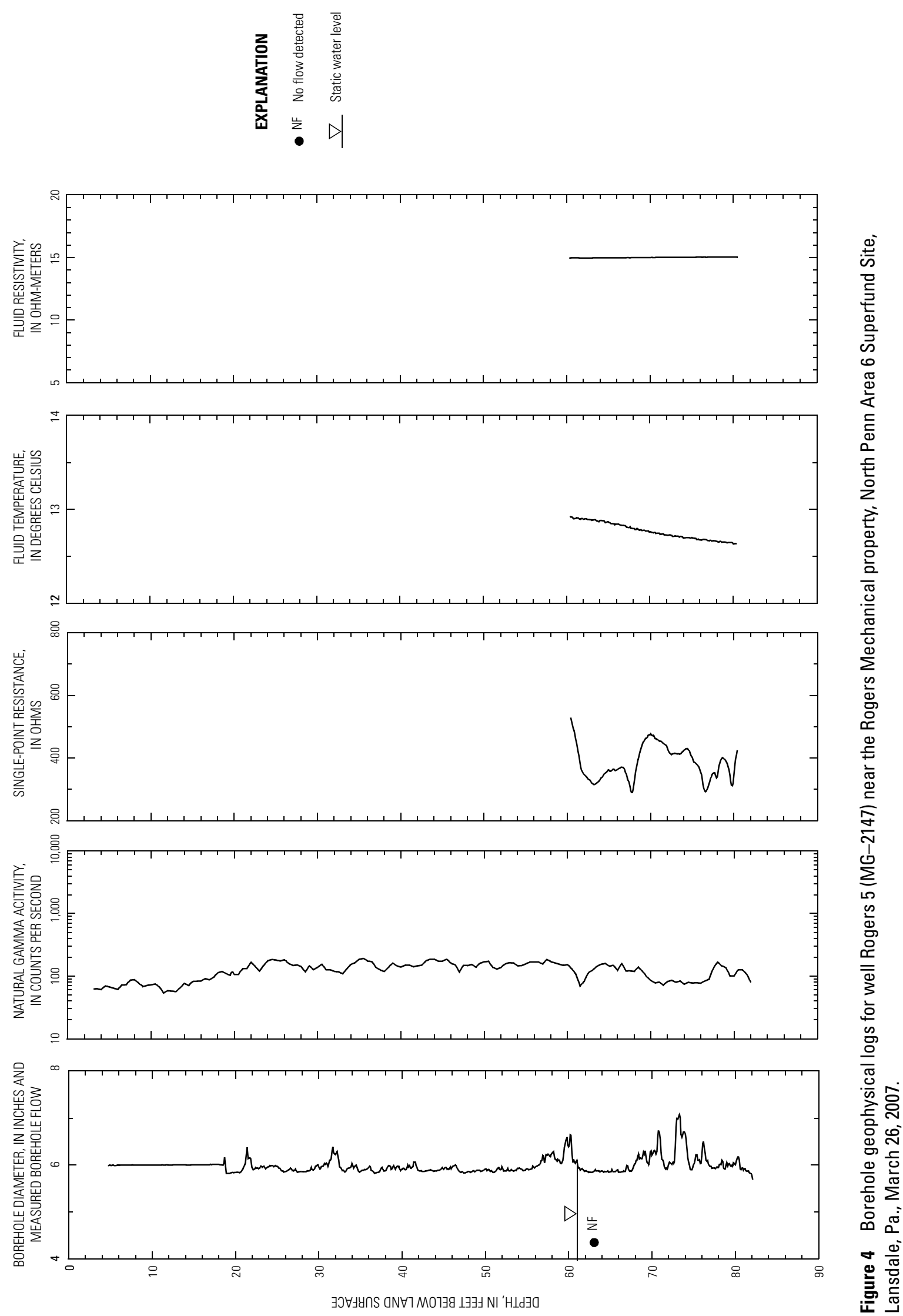


\section{Well Rogers 6 (MG-2148)}

The caliper log shows numerous fractures throughout the 80 -ft borehole, with large fractures indicated at about $42-44$, 57-58, and 64-70 ft bls and smaller fractures at 73-80 ft bls (fig. 5). Possible water-bearing fractures indicated on the caliper $\log$ and noted on the borehole video $\log$ were at 65,68 , and 73-79 ft bls. The video log also showed a fracture at $43 \mathrm{ft}$ bls. Static water level at the time of logging was $59.13 \mathrm{ft}$ bls. The drilling log collected by USGS (table 4) noted water production at $75 \mathrm{ft}$ bls of about $1-2 \mathrm{gal} / \mathrm{min}$.

The natural-gamma log shows relatively low activity throughout the borehole, with a feature of depressed activity about $58 \mathrm{ft}$ bls that might possibly be used for log correlation. The single-point resistance log shows two intervals of increased resistance from 64-67 and 68-71 ft bls that appear to correspond with water-bearing fracture zones. The drilling log (table 4) recorded red shale at about 20-45 ft bls, red to gray-brown shale at 55-65 ft bls, gray shale at 70-74 ft bls, yellow-brown gray shale at $75 \mathrm{ft}$ bls, and black shale at 78-80 ft bls. The thin layer of black shale at the bottom of the well Rogers 6 (MG-2148) appears similar to the gray-to-black shale noted at $80 \mathrm{ft}$ bls in the well Rogers 5 (MG-2147).

The fluid-temperature log shows a decrease in temperature with depth from water level at $59 \mathrm{ft}$ bls to the bottom of the borehole at $80 \mathrm{ft}$ bls. The fluid-resistivity log shows an inflection at about $64 \mathrm{ft}$ bls and a nearly straight profile below $64 \mathrm{ft}$ bls, suggesting a possible water-bearing zone near the depth of inflection. Under non-pumping conditions, no vertical flow was detected at 61 and $71 \mathrm{ft}$ bls. Flow measurements indicate that minor turbulence or possible lateral flow may be present at $71 \mathrm{ft}$ bls. The suite of logs indicate that water-bearing zones in the well most likely are in the interval between 65 and $79 \mathrm{ft}$ bls.

Table 4. Drilling log for well Rogers 6 (MG-2148), at the Rogers Mechanical property, North Penn Area 6 Superfund Site, Lansdale, Pa., March 26, 2007.

\begin{tabular}{cll}
\hline $\begin{array}{c}\text { Depth } \\
\text { (feet below land surface) }\end{array}$ & Lithology & Remarks \\
\hline 20 & red/gray shale & red shale \\
25 & red shale & red shale \\
30 & red shale \\
35 & red shale \\
40 & red/gray/brown shale \\
45 & red/gray/brown shale \\
50 & red/gray/brown shale \\
55 & red/gray/brown shale & \\
60 & medium grey shale & some water; yield 1-2 gallons per minute \\
70 & yellow brown to gray shale & graphite floating? \\
75 & black shale & total depth \\
\hline
\end{tabular}




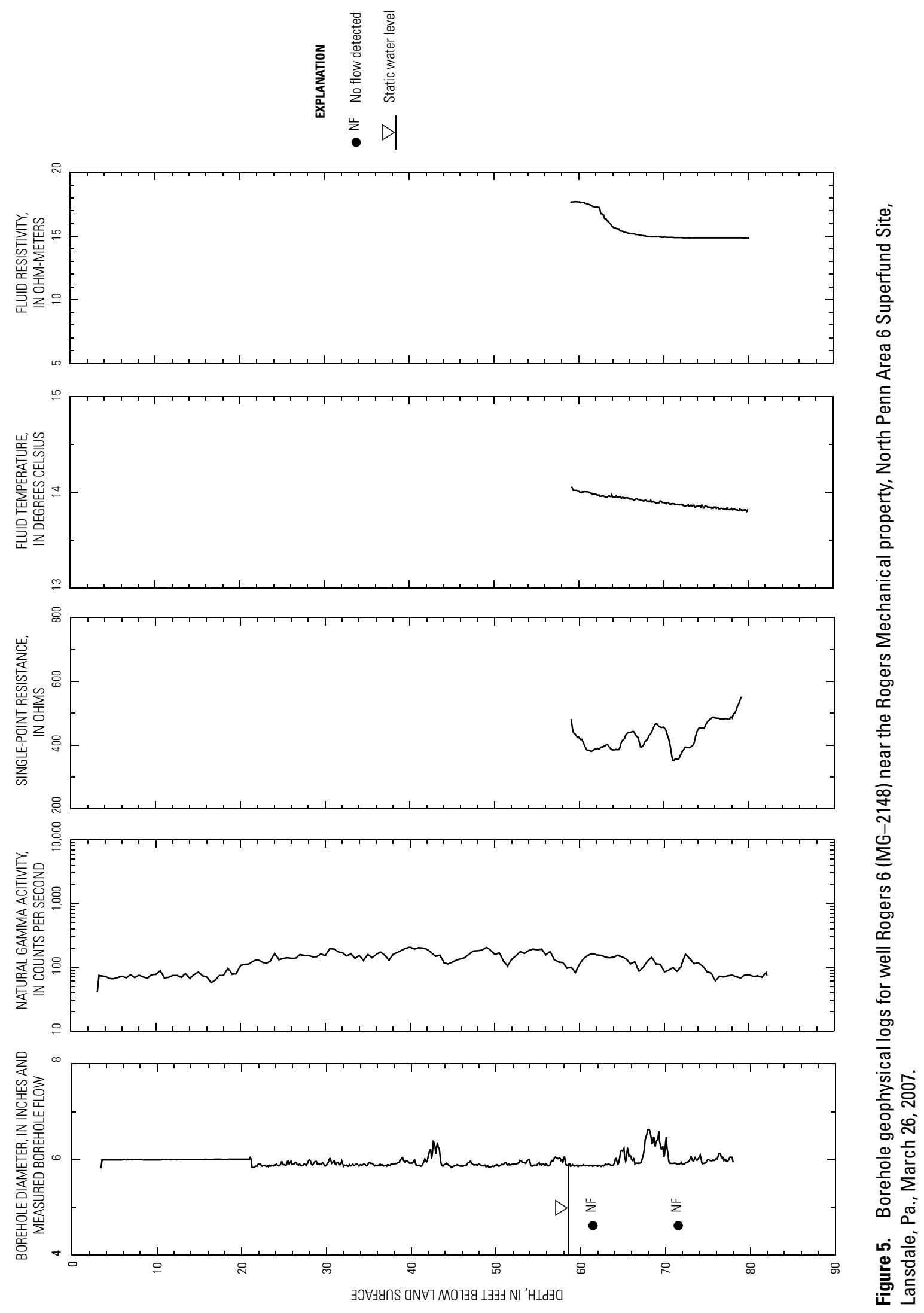




\section{Well Rogers 3S (MG-1601)}

Results of geophysical logging of well Rogers 3S (MG-1601) on May 12, 1997, indicated that there are numerous fractures throughout the 100-ft borehole (Conger, 1999), with large fractures and fracture zones indicated at about 19-24, 27-30, 39-43, 48-76, 84-90, and 95-97 ft bls (fig. 6). At the time of logging in 1997, the static water level was $55.35 \mathrm{ft}$ bls. Under non-pumping conditions, upward flow was measured at 80 and $92 \mathrm{ft} \mathrm{bls}$ and no flow was measured at $65 \mathrm{ft}$ bls (table 5). Interpretation of these logs suggested that water entered the borehole through fractures at 84-90 and 94-95 ft bls, moved upward, and exited the borehole at 66-77 ft bls (Conger, 1999). The low gamma activity measured near $68 \mathrm{ft} \mathrm{bls} \mathrm{(fig.} \mathrm{6;} \mathrm{Conger,} \mathrm{1999)} \mathrm{is} \mathrm{a} \mathrm{feature} \mathrm{that}$ might possibly be used for log correlation.

In April 2007, a borehole video log and a second set of heatpulse-flowmeter logs were collected. The static water level was $56.13 \mathrm{ft}$ bls on April 4, 2007. Possible water-bearing fractures were noted at 85, 93, and $98 \mathrm{ft}$ bls on the borehole video log, which also showed the water to be hazy above $60 \mathrm{ft}$ bls and clearing below $64 \mathrm{ft}$ bls. Under non-pumping conditions, downward flow was measured at 58,65,70, and $97 \mathrm{ft}$ bls and no flow was measured at 80 and $93 \mathrm{ft}$ bls, with possible turbulence or lateral flow at $93 \mathrm{ft}$ bls (table 5). Unsteady flow indicated by unstable measurements at 70 and $97 \mathrm{ft}$ bls may be a response to possible nearby transient pumping, although no nearby well was known to be pumping at the time of logging. Interpretation of the April 2007 measurements suggest that water entered the borehole through fractures near 55-58 ft bls, moved down, and exited through fractures near 60-70 ft bls. Additional water may enter the borehole through fractures at $93 \mathrm{ft}$ bls, move down, and exit the borehole through fractures at $98 \mathrm{ft}$ bls. This set of flow logs indicates different vertical flow conditions in 2007 (downward flow) compared to 1997 (upward flow).

Table 5. Borehole flow determined by heatpulse-flowmeter measurements in well Rogers 3 S (MG-1601) under non-pumping, ambient conditions at the Rogers Mechanical property, North Penn Area 6 Superfund Site, Lansdale, Pa., May 12, 1997, and April 24, 2006.

[ft bls, feet below land surface; gal/min, gallon per minute; NF, no flow detected; --, no data]

\begin{tabular}{cccccc}
\hline \multirow{2}{*}{$\begin{array}{c}\text { Depth of } \\
\text { measurement } \\
\text { (ft bls) }\end{array}$} & \multicolumn{2}{c}{ May 12, 1997} & & \multicolumn{2}{c}{ April 4, 2007 } \\
\cline { 2 - 3 } \cline { 5 - 6 } & $\begin{array}{c}\text { Measured flow } \\
\text { (gal/min) }\end{array}$ & $\begin{array}{c}\text { Direction of } \\
\text { flow }\end{array}$ & & $\begin{array}{c}\text { Measured flow } \\
\text { (gal/min) }\end{array}$ & $\begin{array}{c}\text { Direction of } \\
\text { flow }\end{array}$ \\
\hline 58 & -- & -- & & 0.9 & down \\
65 & NF & -- & & .1 & down \\
70 & -- & -- & & $0-.17$ & down \\
80 & 0.36 & up & & NF & -- \\
92 & .15 & up & & -- & -- \\
93 & -- & -- & & NF & turbulence? \\
97 & -- & -- & & $0-.10$ & down \\
\hline
\end{tabular}



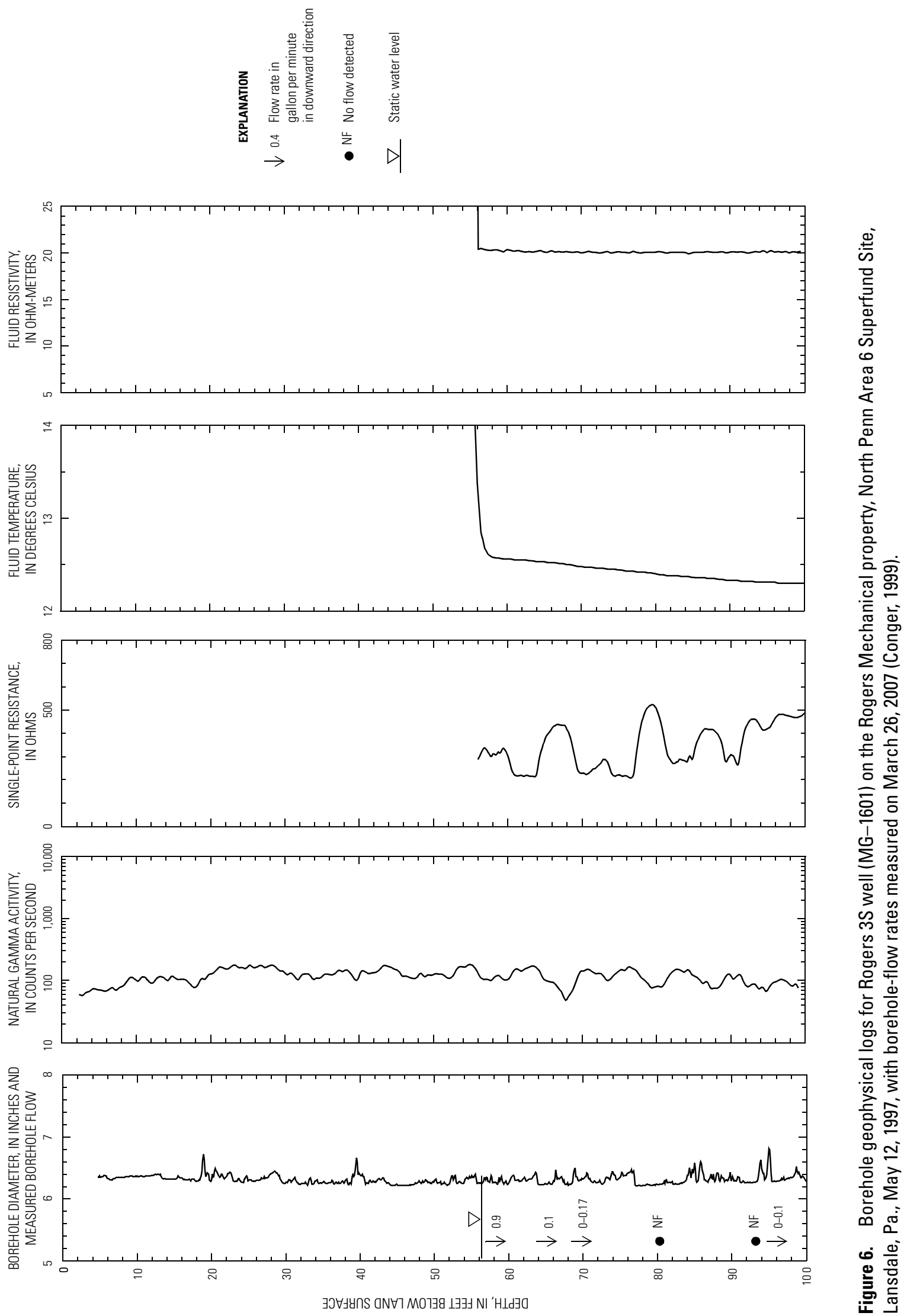


\section{Specific Capacity Determined During Well Development for Wells Rogers 5 (MG-2147) and Rogers 6 (MG-2148)}

The wells Rogers 5 (MG-2147) and Rogers 6 (MG-2148) were developed on March 27, 2007, by pumping conducted by the Black \& Veatch drilling subcontractor. Water levels were recorded by USGS using transducers during pumping at various rates (fig. 7). The specific capacity for each well was estimated for one rate of pumping. For the well Rogers 5 (MG-2147), the specific capacity estimated at the pumping rate of $1.4 \mathrm{gal} / \mathrm{min}$ was $1.27(\mathrm{gal} / \mathrm{min}) / \mathrm{ft}$. For the well Rogers 6 (MG-2148), the specific capacity estimated at the pumping rate of $3.5 \mathrm{gal} / \mathrm{min}$ was $1.34(\mathrm{gal} / \mathrm{min}) / \mathrm{ft}$. Well-loss terms were not determined for drawdowns at various pumping rates because water levels stabilized for only one rate (step) of pumping.

The specific-capacity values estimated for the wells Rogers 5 (MG-2147) and Rogers 6 (MG-2148) during well development are similar or somewhat higher than specific-capacity values for other wells on the Rogers Mechanical property as estimated from pumping and drawdown data recorded when the wells were sampled by Black \& Veatch. For example, specific capacity was estimated to be about $0.55(\mathrm{gal} / \mathrm{min}) / \mathrm{ft}$ for the well Rogers $3 \mathrm{~S}(\mathrm{MG}-1601)$ based on a pumping rate of $6 \mathrm{gal} / \mathrm{min}$ and a drawdown of $11 \mathrm{ft}$ when sampled in October 1997 (Black \& Veatch Waste Science, Inc., 1999).

\section{Water Quality (Volatile Organic Compounds)}

Samples of water at selected depths were collected by Black \& Veatch using the passive-diffusion bag method in the well Rogers 4 (MG-1795) in June and November 2006 (Black \& Veatch Waste Science, Inc., 2007) and in the wells Rogers 3S (MG-1601), Rogers 5 (MG-2147), and Rogers 6 (MG-2148) in May 2007 (Black \& Veatch Waste Science, Inc., written commun., 2007). The passive-diffusion bags were placed at depths determined from interpretation of geophysical logs. Samples were analyzed for selected VOCs. Results show that concentrations of VOC contaminants decrease with depth and generally were greatest in the shallowest intervals in three (Rogers 3S, Rogers 4, and Rogers 5) of the four wells (table 6). Samples from the well Rogers 6 (MG-2148) apparently show an increase with depth, a pattern that would need to be confirmed with additional sampling.

In these rounds of sampling, the highest VOC concentration measured was $240 \mu \mathrm{g} / \mathrm{L}$ of cis-1,2-dichloroethylene (DCE) from the shallowest interval of Rogers 3S (MG-1601). Previous sampling of the well Rogers 3S (MG-1601) in 1997 and 2004 was based on purging the borehole and collecting a pumped sample, which resulted in whole-well sample concentrations less than the those in the diffusion-bag samples. For example, cis-1,2-DCE ranged from 7 to $19 \mu \mathrm{g} / \mathrm{L}$ in whole-well samples (Black \& Veatch Waste Science, Inc., 1999; written commun., 2004) compared to a range of 24-240 $\mu \mathrm{g} / \mathrm{L}$ for diffusion-bag samples (Black \& Veatch Waste Science, Inc., written commun., 2007) (table 6). Other VOCs measured in concentrations greater than the maximum contaminant level (MCL) in these four wells during the 2006-07 diffusion-bag sampling were PCE, TCE, carbon tetrachloride, and 1-1-DCE, with maximum concentrations of 46, 69, 110, and $130 \mu \mathrm{g} / \mathrm{L}$, respectively.

During development of wells Rogers 5 (MG-2147) and Rogers 6 (MG-2148), volatile organic vapors released from purge water were screened using a photoionization detector (PID). Readings as high as 32 parts per million (ppm) were measured during well development of the well Rogers 5 (MG-2147). Readings were not above background ( $0.5 \mathrm{ppm})$ during well development of the well Rogers 6 (MG-2148). 

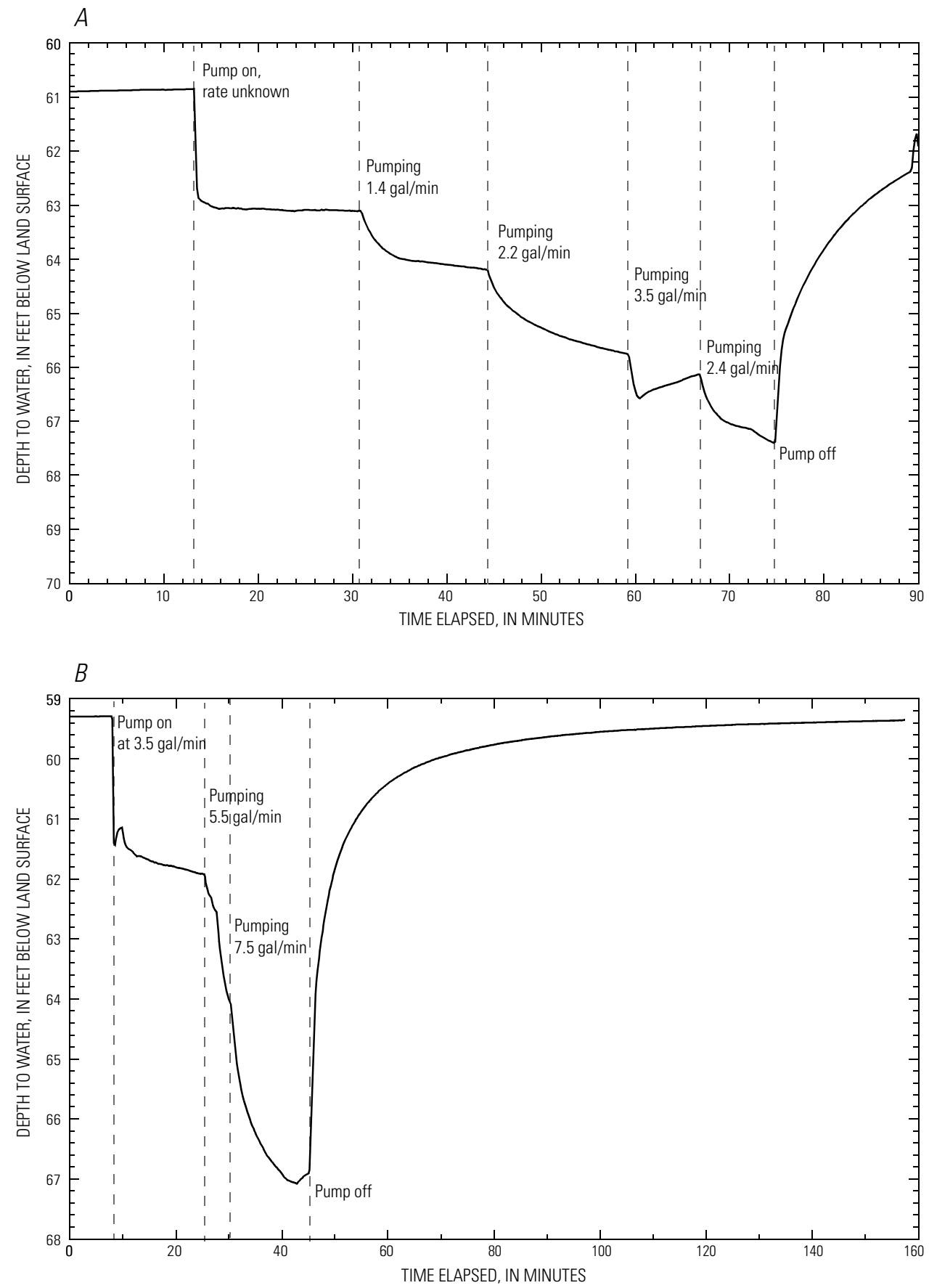

Figure 7. Water levels measured during well development by pumping at various rates in $(A)$ well Rogers 5 (MG-2147) and (B) well Rogers 6 (MG-2148) on the Rogers Mechanical property, North Penn Area 6 Superfund Site, Lansdale, Pa., March 27, 2007. Pumping rates are given in gallons per minute (gal/min). 
Table 6. Depths of passive-diffusion bag placement and concentrations of selected volatile organic compounds in bag samples in wells Rogers 4 (MG-1795), Rogers 5 (MG-2147), Rogers 6 (MG-2148), and Rogers 3S (MG-1601), June 2006-May 2007, and in pumped samples from well Rogers 3S (MG-1601), October 1997 and September 2004, at the Rogers Mechanical property, North Penn Area 6, Lansdale, Pa. [Data from Black \& Veatch Waste Science, Inc. (1999; written commun., 2004; 2007)].

[ft bls, feet below land surface; $\mu \mathrm{g} / \mathrm{L}$, micrograms per liter; PCE, tetrachloroethylene; TCE, trichloroethylene; DCE, dichloroethylene; carbon tet., carbon tetrachloride; TCA, trichloroethane; DCA, dichloroethane; MCL, U.S. Environmental Protection Agency maximum contaminant level in drinking water; --, no data; -, not detected]

\begin{tabular}{|c|c|c|c|c|c|c|c|}
\hline $\begin{array}{c}\text { Depth of } \\
\text { diffusion bag } \\
\text { (ft bls) }\end{array}$ & $\begin{array}{l}\text { PCE } \\
(\mu \mathrm{g} / \mathrm{L})\end{array}$ & $\begin{array}{c}\text { TCE } \\
(\mu \mathrm{g} / \mathrm{L})\end{array}$ & $\begin{array}{c}\text { cis-1,2-DCE } \\
(\mu \mathrm{g} / \mathrm{L})\end{array}$ & $\begin{array}{l}\text { Carbon tet. } \\
(\mu \mathrm{g} / \mathrm{L})\end{array}$ & $\begin{array}{c}\text { 1,1-DCE } \\
(\mu \mathrm{g} / \mathrm{L})\end{array}$ & $\begin{array}{c}\text { 1,1,1-TCA } \\
(\mu \mathrm{g} / \mathrm{L})\end{array}$ & $\begin{array}{c}1,1-D C A \\
(\mu g / L)\end{array}$ \\
\hline $\mathrm{MCL}$ & 5 & 5 & 70 & 5 & 7 & 200 & -- \\
\hline \multicolumn{8}{|l|}{$\begin{array}{l}\text { Rogers } 4 \\
\text { June } 19,2006\end{array}$} \\
\hline 69-71 & 7.9 & 67 & 5.1 & 15 & 9.4 & 1.3 & 1.4 \\
\hline 81-83 & 6.7 & 69 & 6.4 & 10 & 10 & 1.4 & 1.2 \\
\hline 99-101 & .56 & 11 & .96 & 1.1 & - & - & - \\
\hline 115-117 & .54 & 11 & .82 & 1.0 & .67 & - & - \\
\hline 139-141 & .53 & 6.4 & .54 & .62 & - & - & - \\
\hline 159-161 & - & 5 & - & .52 & - & - & - \\
\hline \multicolumn{8}{|l|}{$\begin{array}{l}\text { Rogers } 4 \\
\text { November 7, } 2006\end{array}$} \\
\hline 69-71 & 13 & 32 & 2.1 & 110 & 2.9 & .46 & .55 \\
\hline $81-83$ & 9.9 & 46 & 3.6 & 77 & 5.4 & .88 & 1 \\
\hline 99-101 & .56 & 9.9 & 1.2 & 1.5 & .61 & .19 & .15 \\
\hline $115-117$ & .74 & 9.9 & 1.2 & 1.5 & .63 & .19 & .14 \\
\hline 139-141 & .77 & 7.3 & .92 & 1.1 & .53 & .16 & .11 \\
\hline 159-161 & .75 & 6.9 & .86 & 1.1 & .5 & .15 & .11 \\
\hline \multicolumn{8}{|l|}{$\begin{array}{l}\text { Rogers } 5 \\
\text { May 2, } 2007\end{array}$} \\
\hline $67-69$ & .56 & 43 & 1.2 & - & - & - & - \\
\hline 71-73 & .4 & 26 & .90 & - & - & - & - \\
\hline \multicolumn{8}{|l|}{$\begin{array}{l}\text { Rogers } 6 \\
\text { May 2, } 2007\end{array}$} \\
\hline 64-66 & & .44 & & - & - & - & - \\
\hline $67-69$ & & 5.7 & 0.52 & - & - & - & - \\
\hline 76-78 & & 42 & 6.1 & - & - & - & - \\
\hline \multicolumn{8}{|l|}{$\begin{array}{l}\text { Rogers 3S } \\
\text { May 2, } 2007\end{array}$} \\
\hline $57-59$ & 33 & 31 & 240 & - & 130 & 22 & 31 \\
\hline 64-66 & 31 & 32 & 210 & - & 120 & 19 & 26 \\
\hline $83-85$ & 46 & 38 & 150 & .85 & 54 & 24 & 20 \\
\hline 92-94 & 10 & 8.4 & 23 & 1.1 & 10 & 4.7 & 3.7 \\
\hline 96-98 & 11 & 9.8 & 24 & 1.4 & 11 & 5.4 & 4.1 \\
\hline \multicolumn{8}{|l|}{$\begin{array}{l}\text { Rogers 3S } \\
\text { October } 1997\end{array}$} \\
\hline whole well pumped & 3.4 & 16.7 & 7 & 2.6 & 1.3 & 2.4 & - \\
\hline \multicolumn{8}{|l|}{$\begin{array}{l}\text { Rogers 3S } \\
\text { September } 2004\end{array}$} \\
\hline whole well pumped & 13 & 8.8 & 19 & 1.1 & 5.9 & 3.3 & - \\
\hline
\end{tabular}




\section{Summary}

In 2006-07, the U.S. Geological Survey (USGS) collected borehole geophysical logs, video logs, and water-level data as part of technical assistance to the U.S. Environmental Protection Agency (USEPA) at the Rogers Mechanical (former Tate Andale) property on the North Penn Area 6 Superfund Site, Lansdale Pa. On the basis of data collected through 2004, groundwater contamination with VOCs was thought to be highest on the western side of the property in monitor well Rogers $3 \mathrm{~S}$ (MG-1601) and in the shallowest water-bearing intervals of the former production well (MG-1444). The geophysical logs were used to identify water-bearing fractures and direction of borehole flow. These data were later used by the USEPA contractor to set the depths of passive-diffusion bags to collect samples at various depths to determine the vertical distribution of contamination in selected wells on the property.

In 2006, USGS collected borehole geophysical and video logs in a 180-ft deep new monitor well, Rogers 4 (MG-1795). Borehole flow under non-pumping conditions was downward in the upper part of the well and upward in the lower part of the well. In 2007, USGS collected drilling logs and borehole geophysical and video logs in two new monitor wells, Rogers 5 (MG-2147) and Rogers 6 (MG-2148), that were 82 and $80 \mathrm{ft}$ deep, respectively. No borehole flow was measured in either new well under non-pumping conditions. Static water levels in wells Rogers 4 (MG-1795), Rogers 5 (MG-2147), and Rogers 6 (MG-2148) at the time of logging in 2006-07 ranged from about 57.3 to $60.6 \mathrm{ft}$ below land surface. In 2007, borehole flow was re-measured in the well Rogers 3S (MG-1601), a well that was previously logged by USGS in 1997, and was shown to be predominantly downward in 2007 compared to largely upward in 1997. The static water level in the well Rogers 3S (MG-1601) at the time of logging was about $56.1 \mathrm{ft}$ bls in 2007 and $55.4 \mathrm{ft}$ bls in 1997.

Water levels were measured during development of the two new monitor wells, Rogers 5 (MG-2147) and Rogers 6 (MG-2148), and used to estimate well specific capacities of 1.27 and $1.34(\mathrm{gal} / \mathrm{min}) / \mathrm{ft}$, respectively.

Results of samples collected from passive-diffusion bags set at depths determined from the geophysical logs showed that concentrations of VOC contaminants decreased with depth and generally were greatest in the shallowest intervals in three (Rogers 3S, Rogers 4, and Rogers 5) of the four wells tested. Samples from the well Rogers 6 (MG-2148) showed a slight increase in VOC concentrations with depth, a pattern that would need to be confirmed with additional sampling.

\section{References Cited}

Black \& Veatch Waste Science, Inc., 1999, Remedial Investigation Feasibility Study Report North Penn Area 6 Site Groundwater Operable Unit (OU3), Lansdale, Pennsylvania: Prepared for the U.S. Environmental Protection Agency, Work assignment no. 004-RICO03W9, contract no. 68-S8-3002, August 1999.

Black \& Veatch Waste Science, Inc., 2007, Data Evaluation Report, Diffusion bag sampling, pump test sampling and groundwater level measurements, North Penn Area 6 OU3 Phase 2 RD, Lansdale, Montgomery County Pennsylvania: Prepared for U.S. Environmental Protection Agency, work assignment 056-RDRD03W9, Black \& Veatch project no. 047127.01.26, January 2007.

Conger, R.W., 1999, Analysis of geophysical logs, at North Penn Area 6 Superfund Site, Lansdale, Montgomery County, Pennsylvania: U.S. Geological Survey Open-File Report 99-271A, 149 p.

Goode, D.J., and Senior, L.A., 1998, Review of aquifer tests for the Lansdale area, Montgomery County, Pennsylvania: U.S. Geological Survey Open-File Report 98-294, 70 p.

Goode, D.J., and Senior, L.A., 2000, Simulation of aquifer tests and ground-water flowpaths at the local scale in fractured shales and sandstones of the Brunswick Group and Lockatong Formation, Lansdale, Montgomery County, Pennsylvania: U.S. Geological Survey Open-File Report 00-97, 46 p.

Lyttle, P.Y., and Epstein, J.B., 1987, Geologic map of the Newark $1^{\circ} \times 2^{\circ}$ quadrangle, New Jersey, Pennsylvania, and New York: U.S. Geological Survey Miscellaneous Investigations Series Map I-1715, scale 1:250,000.

Senior, L.A., and Goode, D.J., 1999, Ground-water system, estimation of aquifer hydraulic properties, and effects of pumping on ground-water flow in Triassic sedimentary rocks in and near Lansdale, Pennsylvania: U.S. Geological Survey WaterResources Investigations Report 99-4228, 112 p.

Senior, L.A., Rowland, C.J., and Prieto, D.A., 1998, Altitude and configuration of the potentiometric surface in Lansdale and vicinity, Montgomery County, Pennsylvania, August 22-23, 1996: U.S. Geological Survey Open-File Report 98-253, 1 plate, scale $1: 24,000$. 


